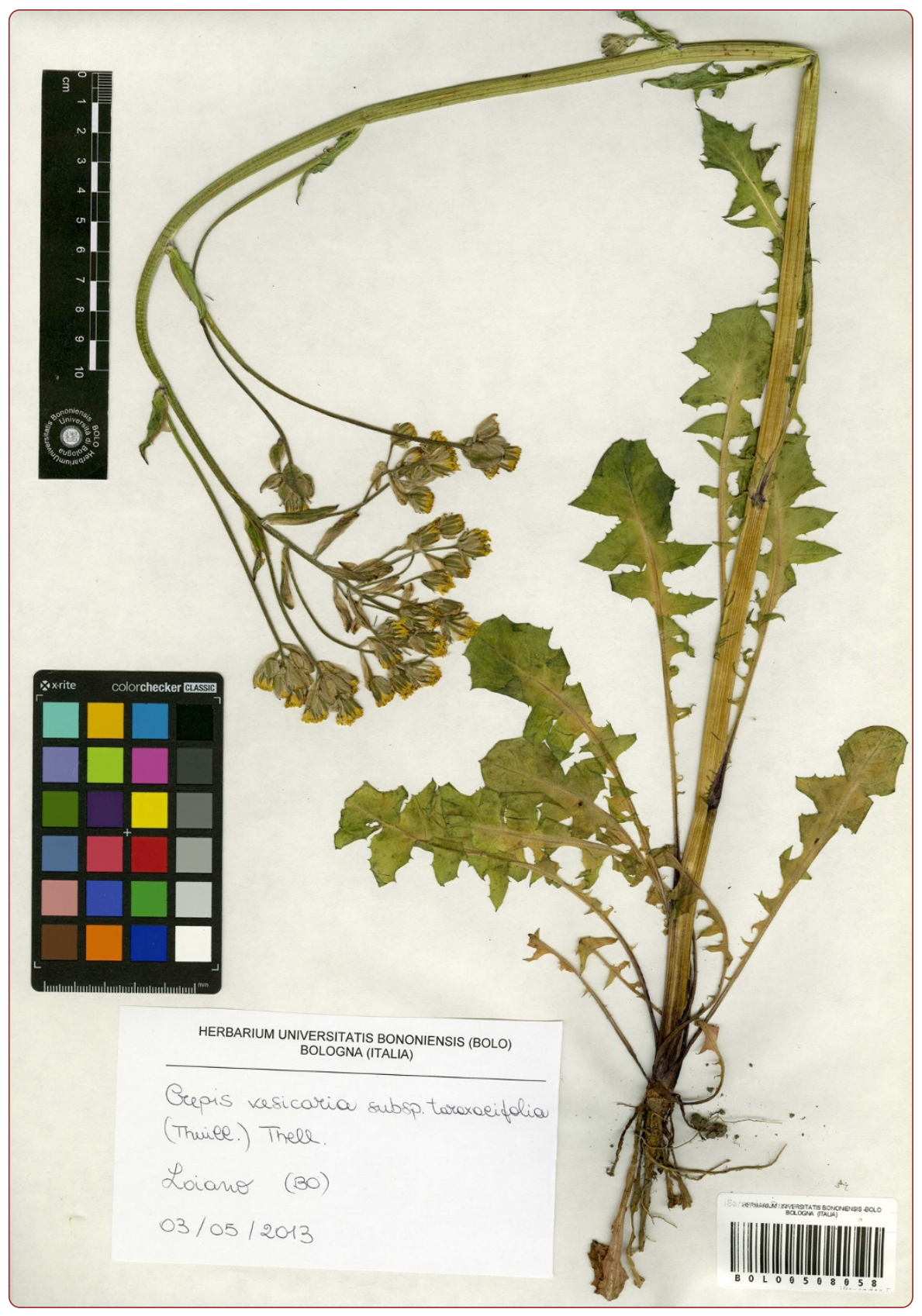

\title{
Wild food plants traditionally consumed in the area of Bologna (Emilia Romagna region, Italy)
}

Sansanelli and Tassoni 


\title{
Wild food plants traditionally consumed in the area of Bologna (Emilia Romagna region, Italy)
}

\author{
Sabrina Sansanelli and Annalisa Tassoni ${ }^{*}$
}

\begin{abstract}
Background: This research was performed in an area belonging to the province of the city of Bologna (Emilia-Romagna region, Northern Italy). The purpose of the present survey was to record the local knowledge concerning traditional uses of wild food plants and related practices, such as gathering, processing, cooking, therapeutic uses, with the aim of preserving an important part of the local cultural heritage.

Methods: Thirty-nine people still retaining Traditional Local Knowledge (TLK) were interviewed between March-April 2012 and September - October 2013 by means of open and semi-structured ethnobotanical interviews. For each plant species mentioned, we recorded the botanical family, the English common name, the Italian common and/or folk names, the parts of the plant used, the culinary preparation, and the medicinal usage. The relative frequency of citation index (RFC), a tool that measures the local cultural importance of a plant species, was also included.

Results: The folk plants mentioned by the respondents belonged to 33 botanical families, of which the Rosaceae (14 plants) and the Asteraceae (9 plants) were the most representative. The species with the highest RFC index (0.77) were Crepis vesicaria subsp. taraxacifolia (Thuill) Thell and Taraxacum officinale Weber. Eleven folk plants were indicated as having therapeutic effects. T. officinale Weber, C. vesicaria subsp. taraxacifolia (Thuill) Thell and Sonchus spp., which are used as food, were reported to be depurative, blood cleaning, refreshing, diuretic and laxative. The most commonly used species was Urtica spp, which was also the most frequently cited for medicinal uses.

Conclusions: The present survey documented the wild food plant traditional knowledge of an area belonging to the province of the city of Bologna (Emilia-Romagna region, Northern Italy). The general perception obtained is that on one side the TLK related to wild food plants has strongly been eroded, mainly due to immigration and urbanization phenomena, whereas on the other side these plants are revaluated today because they are perceived as healthy and also because they represent the preservation of biodiversity and a way of getting back to nature.
\end{abstract}

Keywords: Ethnobotany, Traditional local knowledge, Wild food plants, Bologna, Emilia-Romagna region, Crepis vesicaria subsp. taraxacifolia, Urtica spp

\section{Background}

Before the so-called economic boom (1950-1970), Italy was mainly an agriculture-based economy and society. Poverty, dryness and wars made it difficult to meet subsistence needs [1] and, therefore, edible wild plants represented an alternative food source or sometimes the only one [2]. Wild food plant gathering practices and their way of consumption were slowly integrated into the customs of a territory, becoming part of the Traditional Local Knowledge (TLK). The process of industrialization and

\footnotetext{
* Correspondence: annalisa.tassoni2@unibo.it

Department of Biological, Geological and Environmental Sciences, University of Bologna, Via Irnerio 42, 40126 Bologna, Italy
}

urbanization changed the way of living and society, which became less and less rural. The use of mechanized agriculture and the development of transport improved the availability of vegetables and, consequently, wild food plant practices and the related local knowledge, strongly connected with rural societies, almost totally disappeared. Furthermore, intensive agriculture, which generally involved extensive use of pesticides, and pollution largely impaired wild flora biodiversity, reducing the availability of some wild plants used as food in the past.

The majority of ethnobotanical research has been preferentially focused on traditional medicinal plants [3,4], giving less attention to wild food plants, however, over 
the last two decades, an increasing interest in wild food plants, even in modern societies, has led to many local ethnobotanical studies [5-7]. The international political attention towards biodiversity topics and its links to nutrition and health (Convention on Biological Diversity in 1992, Year of Biodiversity in 2010) has surely contributed in driving forward wild food plants research. Several researches demonstrated that many edible wild plants have nutritional or therapeutic value due to the presence of biologically active compounds and, therefore, they can be considered as food-medicine [8-10]. For example Tamus communis and Humulus lupulus contain a high amount of, respectively, citric and malic acids, antioxidants which are beneficial to health due to their ability to chelate metals [8]; Borago officinalis resulted to be a source of $\gamma$ linoleic acid and other fatty acids that are precursors to mediators of the inflammatory response [9]; Raphanus raphanistrum showed anti-diabetic and anti-proliferation activities while Cynara cardunculus demonstrated a high mood-disorder regulating activity [10].

Wild food plants are generally characterized by high nutritional and low energy values [11]. In comparison to the corresponding cultivated species, wild food plants have a higher fibre content [12], are rich in antioxidants and flavonoids [13] and contain very low amounts of lipids [11]. Many were proven to have important beneficial effects in preventing several chronic diseases of modern society, such as age-related and heart pathologies, diabetes and some types of cancer $[10,11,14,15]$. In the Mediterranean area, the use of wild food plants was thoroughly investigated during the years 2003-2005 by the European Unionfunded RUBIA Project [16]. The selected study sites were Albania, Cyprus, Egypt, Greece, Italy, Morocco and Spain, countries in which the way of using wild plants, closely related to traditions, environment and cultural heritage, varied greatly. Although the most reported species were sometimes the same (e.g. belonging to Asteraceae and Lamiaceae families), their cultural importance varied among the different areas. The habit of using wild food plants played an important role in the life of Mediterranean rural people, however, the spread of plant folk uses has been progressively decreasing over the last generations, and is particularly evident in urban areas [16,17]. In Italy, a comparative ethnobotanical study on wild food plants analysing twenty-one communities located throughout the Italian peninsula, including the islands of Sardinia and $\mathrm{Si}$ cily, produced a comprehensive picture of the country [18]. This survey showed several differences in the use of wild plants, with few botanical species mentioned in more than one area and in particular Borago officinalis present in both Southern and Northern Italian sites. The most important difference was the prevalence of the Rosaceae family in the North, while species belonging to Asteraceae, Brassicaceae and Liliaceae were most frequently cited in the South of
Italy. In general, the results showed that in Southern Italy the erosion of wild TLK plants was happening at a slower rate than in Northern Italy [18].

Changes in the contemporary use of wild food plants in Italy and other European countries have also been recently studied [19]. The results confirmed that the traditional use of wild edibles has been steadily decreasing in association with new phenomena appearing in modern societies, such as the presence of new ethnic minorities that maintain their own traditions and food habits [19].

The study area of the present survey comprised part of the territory of the province of Bologna located in the Emilia-Romagna region (Northern Italy), one of the more economically developed regions of Italy. In this area, after the end of Second World War, many socio-economic changes occurred bringing economic well-being, industrial activities and the development of new transport infrastructures that well connected people, houses, services and workplaces. These changes inevitably mutated the lifestyle, the family system and the nature of communities. The local knowledge, shared among family and community members, was thus less and less passed down to the following generations. The aim of the present paper is to record local knowledge concerning the traditional uses of wild food plants as well as related practices such as gathering, processing, cooking and therapeutic uses. Up till now no research has been carried out on the use of wild food plants in this territory and, therefore, this study represents the first attempt to collect and save from oblivion an important part of the cultural heritage preserved by this population.

\section{Methods}

Fieldwork was conducted in a study area belonging to the Bologna province (Emilia-Romagna region, Northern Italy) comprised between the Panaro river (to the north-west), the Santerno river (to the south-east), the Ferrara province (to the north-east), the Apennine mountains (to the south-west) (Figure 1). The survey was performed during the following periods: March-April 2012 and September - October 2013. Ethnobotanical information was collected by standard ethnobotanical tools [20], such as participant observation, as well as open and semi-structured interviews. A questionnaire form, used as a guideline for the ethnobotanical interviews, is reported in the Additional file 1. Thirty-nine people still retaining Traditional Local Knowledge (TLK) were interviewed. The respondents were identified after having contacted several local associations for elderly people. All participants as well as their parents were born and had always lived in the study area (Figure 1). The origin of the family home is of extreme importance as TLK is formed and handed down mainly within the family. However, it was not easy to find people who 

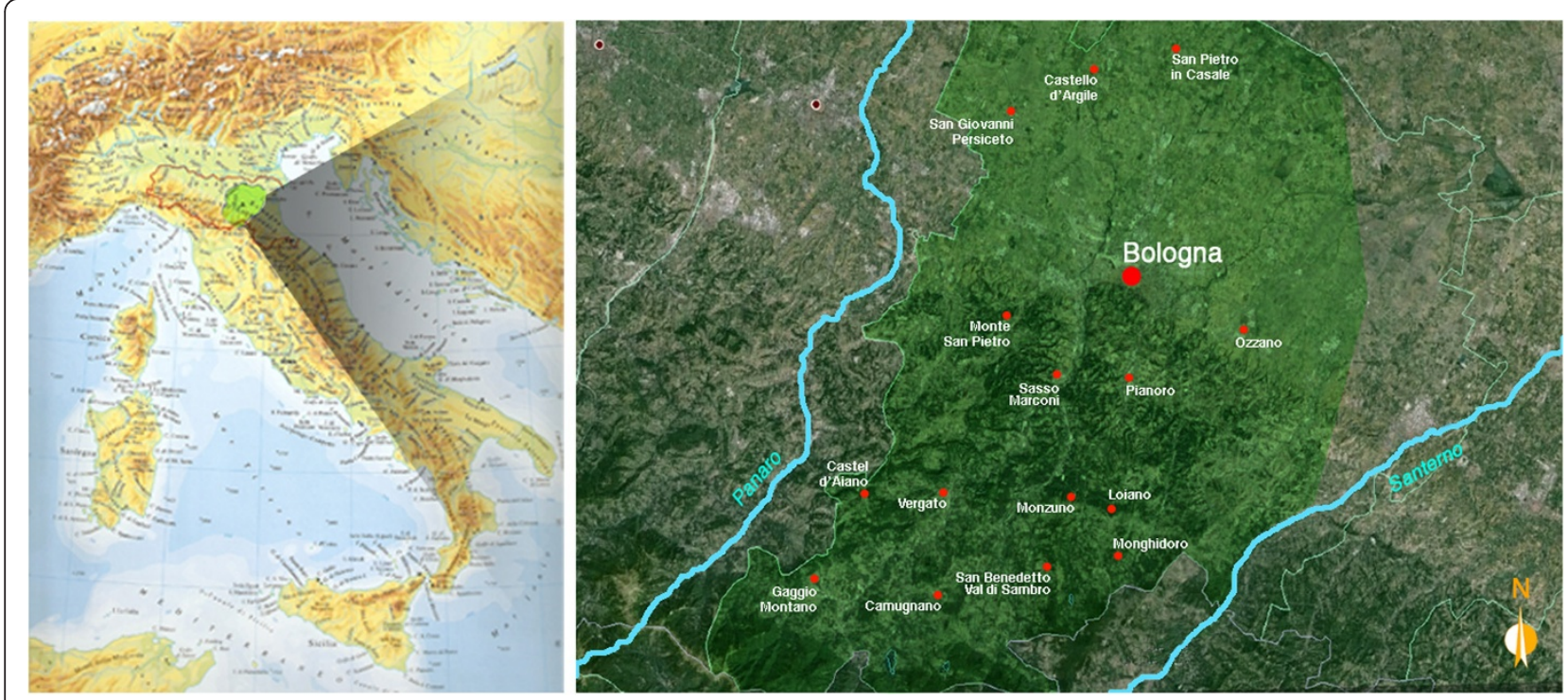

Figure 1 Location of the study area.

satisfied these selection criteria, as the province of Bologna is an area with a high rate of immigration and a high level of urbanization that presumably greatly contributed to the loss of TLK. Conversations and discussions were also made with people working in vegetarian restaurants, organic farms and botanical gardens to obtain information on the actual use and knowledge of wild food plants. The purpose, method and nature of the research were previously explained and informed consent was obtained from all informants. Interviews were carried out both individually and in groups. When conducted in groups, the respondents were stimulated to express their personal experience. During the first phase of the interview, the informants were asked to freely recall all the wild plant species that they had used in the past and/or were presently using for food purposes. For each plant species mentioned, the informants were asked to state the folk name, the parts of plant used, the period of harvesting, culinary and other possible uses, the frequency of use and whether they had used the plant in the past or were still using it. Processing and cooking activities were also precisely described. The respondents were able to speak freely but sometimes it was necessary to encourage them providing some suggestions (e.g. "have you ever seen/used this plant?") just to help them to recall the memories of decades ago. Particular attention was paid to the therapeutic effects that may have been perceived after ingestion of some particular wild food plant. Moreover, the medicinal use of plants, with specific modes of preparation and application, were always addressed. The perception of wild species in relation to their cultivated analogues and the possible impacts, benefits or risks on human nutrition and health, were also investigated. The taste and level of appreciation of the consumed plant species were described.

For each mentioned plant species a relative frequency of citation index (RFC) was calculated. The RFC index expresses the number of informants who cited a specific wild food plant divided by the total number of informants. It was used to assess the local importance of each species and may vary from 0 , when nobody refers to the plant as useful, to 1, when all informants mention the use of a species [21]. Three informants who were particularly knowledgeable on wild food plants and still using them, were chosen as key informants to become involved in participant observations and their interviews were implemented to better understand the way of plant collection, food preparation, gender relation and mode of passing down local knowledge. The key informants were also helpful and active in gathering the mentioned wild food plant species, which they called by the relative folk or Italian common names. The collected wild plants specimens were successively identified by expert botanists (Dr. Mossetti Umberto and Dr. Managlia Annalisa of the University of Bologna), and renamed following standard botanical nomenclature [22]. To find the correspondence between folk and scientific names, a booklet regarding the names of plants used in the popular tradition of Bologna [23] resulted to be very useful to address and speed up botanical identification. Voucher specimens of the wild food plant species were collected and deposited in the Herbarium of the University of Bologna. 


\section{Results and discussion Informants}

Thirty-nine people, 25 women (64\%) and 14 men (36\%), were interviewed. The age of the informants ranged between 48 and 92, with a mean of 71 and a median of 75 . Nine informants were younger than 60,10 were aged between 60 and 75, and 20 were older than 75. Finding persons who still retained TLK about wild food plants uses was particularly difficult. This shows that much of the local knowledge has already been lost and that it is necessary and urgent to carry out this kind of research in this territory. The results showed that TLK was almost equally shared between the two genders (the average number of species quoted per gender was: 10.2 for women and 9.1 for men), however, the women gave much more details and information on the traditional wild food plants used. Women had a better preserved memory of it probably because the processing and cooking of wild plants were almost exclusively done by them while gathering activities were carried out by both genders. These data are partially in agreement with several studies performed in the Mediterranean area [24-26] that showed that women are the major depositaries of wild plant local knowledge.

Many conversations with people working in vegetarian restaurants, organic farms and botanical gardens led to understand that the traditions about wild food plants were very little known and shared among local population. However there is a part of society that is very careful about healthy and genuine diet and so very interested toward wild food plants (independently from their popular traditions) because considered rich of healthy components and, as study area is a highly anthropomorphized environment, a way to get closer to nature.

\section{Wild food plant data}

The informants mentioned a total of 66 wild food plants (Table 1), including greens (leafy plants eaten as vegetables), fruits and semi-wild plants. The mean number of species quoted per informant was 9.8. Wild plants used for making liqueurs (in particular digestive liqueurs) were also taken into consideration, because these are traditionally drunk at the end of a meal. The wild edible plants mentioned are reported in Table 1 which lists the botanical species and family name, English and Italian common names, Italian folk names (when available), the parts of the plant used, the culinary and medicinal usage and the RFC. Most of the recorded species are commonly used in the Mediterranean area, such as Cichorium intybus L., Sonchus asper L., Borago officinalis Weber, Papaver rhoeas L. [12] (Table 1), whereas others are mainly eaten in Northern and Central Italy, such as Bellis perennis L., and Capsella bursa-pastoris (L.) Med. [18]. The RFC ethnobotanical index indicates, for a given folk species and analysed area, the degree of knowledge shared among the informants. The RFC may vary from 0 to 1 , consequently, a RFC value close to 1 indicates that a species is very important from a cultural and traditional point of view. The highest RFC index (0.77) was found for Crepis vesicaria subsp. taraxacifolia (Thuill) Thell and Taraxacum officinale Weber. C. vesicaria subsp. taraxacifolia (Thuill) Thell is known by the folk name strecapugno, while $T$. officinale Weber is known as piscialét. C. vesicaria subsp. taraxacifolia (Thuill) Thell is more appreciated than T. officinale Weber because of its bitter, slightly crisp flavour, the memory of which is well preserved, even in people who do not consume it anymore. Moreover, T. officinale Weber is a species widely known in Italy and abroad, not only as an edible plant, but also for its therapeutic properties used for depurative and digestive purposes and for mitigating hepatic diseases. Its high availability and characteristic ripe fruits make the plant easy to find and to collect. On the contrary, $C$, vesicaria subsp. taraxacifolia (Thuill) Thell, as revealed by the people interviewed, is not easy to recognise and quite difficult to find. The subspecies taraxacifolia of C. vesicaria is also consumed in other areas throughout Central Italy, often as a substitute for C. vesicaria $\mathrm{L}$. subspecies vesicaria and Crepis biennis $\mathrm{L}$. [27]. C. vesicaria L. subspecies vesicaria is also present in the study area but people identify, collect and consume only the subspecies taraxacifolia. No information is available on knowledge and collection of C. biennis L..

Other wild plants which scored a high RFC index value were: Urtica spp. (0.74), Clematis vitalba L. (0.51), Valerianella locusta L. (Laterrade) (0.41), C. intybus L. and Diplotaxis tenuifolia L. (DC) (0.38) and Sonchus spp. (0.33) (Table 1).

In particular, Urtica spp. resulted to be the most consumed species and is much more valued today than it was in the past. This plant is in fact well integrated in homemade local cooking (e.g. to make green pasta, or to fill and season hand-made pasta) and dishes containing Urtica are proposed by several local restaurants. The wide use of Urtica may also depend on the fact that is a ruderal plant, characterized by a rapid growth close to people's residences, thus being readily available for collection and consumption.

In the present survey, herbs used to make hot beverages (decoctions or infusions) such as Malva sylvestris L. and Matricaria chamomilla L. were not considered as foods (not included in Table 1), but classified as medicinal plants having therapeutic effects.

A large group of plant species listed (19), were mentioned by a single informant for this reason they may be considered as uncertain data (Table 1). These results point out how strongly eroded is the knowledge about wild food plants in the study area. The data obtained in 
Table 1 List of the wild food plants used in the study area

\begin{tabular}{|c|c|c|c|c|c|c|c|}
\hline Botanical name & RFC & $\begin{array}{l}\text { Botanical } \\
\text { family }\end{array}$ & $\begin{array}{l}\text { English common } \\
\text { name }\end{array}$ & $\begin{array}{l}\text { Italian common and/or } \\
\text { folk names }\end{array}$ & $\begin{array}{l}\text { Parts of the plant } \\
\text { used }\end{array}$ & Culinary use & $\begin{array}{l}\text { Medicinal use (preparation } \\
\text { and administration) }\end{array}$ \\
\hline Achillea ptarmica L.* & 0.03 & Asteraceae & sneezewort & achillea & flowers & salads & \\
\hline Allium schoenoprasum L.* & 0.03 & Liliaceae & chives & erba cipollina & leaves & flavouring & \\
\hline Allium ursinum $L^{*}{ }^{*}$ & 0.03 & Liliaceae & wild garlic & aglio selvatico & bulbs & flavouring & \\
\hline Asparagus acutifolius L. & 0.15 & Asparagaceae & wild asparagus & asparago selvatico/asparagina & shoots & salads, pan-fried & \\
\hline Bellis perennis $L .^{*}$ & 0.03 & Asteraceae & common daisy & margheritina & young leaves & salads & \\
\hline Borago officinalis $L$. & 0.08 & Boraginaceae & starflower & borragine & leaves & salads, pancakes, pies & \\
\hline Calamintha nepeta L.* & 0.03 & Lamiaceae & lesser calamint & nepetella & leaves & salads & \\
\hline Calendula officinalis L.* & 0.03 & Asteraceae & common marigold & calendula & flowers & salads & \\
\hline Capsella bursa pastoris L.* & 0.03 & Brassicaceae & shepherd's-purse & borsa del pastore & young leaves & salads & \\
\hline Castanea sativa Mill. & 0.10 & Fagaceae & chestnut & castagno & fruits & fresh fruits & \\
\hline Cichorium intybus L. & 0.38 & Asteraceae & wild chicory & $\begin{array}{l}\text { cicoria selvatica/ radećć, } \\
\text { radećć cavdagn }\end{array}$ & young leaves & salads, pan-fried & \\
\hline Clematis vitalba L. & 0.51 & Ranuncolaceae & traveller's joy & vitalba/vizeibra & shoots & $\begin{array}{l}\text { salads, pan-fried, omelettes, } \\
\text { mixed vegetables }\end{array}$ & \\
\hline Cornus mas L. & 0.05 & Cornaceae & cornelian cherry & corniolo & fruits & rural snack, liqueurs & \\
\hline Corylus avellana L. & 0.05 & Corylaceae & common hazel & nocciolo & fruits & fresh fruits & \\
\hline Crataegus azarolus L.* & 0.03 & Rosaceae & azarole & azzeruolo/lazaren & fruits & rural snack & \\
\hline Crataegus monogyna Jacq. & 0.15 & Rosaceae & common hawthorn & biancospino/spen bianc & fruits, shoots, leaves & rural snack & $\begin{array}{l}\text { Relaxing, insomnia and heart } \\
\text { problems (flowers infusion) }\end{array}$ \\
\hline Crepis sancta (L.) Babc. & 0.15 & Asteraceae & hawk's-beard & radicchiella/ciocapiat & young leaves & salads, pan-fried & Diuretic and laxative (food) \\
\hline $\begin{array}{l}\text { Crepis vesicaria subsp. } \\
\text { taraxacifolia (Thuill.) Thell. }\end{array}$ & 0.77 & Asteraceae & beaked hawk's beard & radicchiella/strecapugno & young leaves & $\begin{array}{l}\text { salads, pan-fried, omelettes, } \\
\text { pasta dough }\end{array}$ & $\begin{array}{l}\text { Depurative, refreshing, blood } \\
\text { cleaning, diuretic, laxative } \\
\text { (cooking water, food) }\end{array}$ \\
\hline Diplotaxis tenuifolia L. (DC) & 0.38 & Brassicaceae & wall rocket & rucola selvatica & leaves & salads & \\
\hline Fagus sylvatica L.* & 0.03 & Fagaceae & common beech & al fasoli (fruits) & fruits & rural snack & \\
\hline Ficus carica L. & 0.05 & Moraceae & common fig & fico & fruits & fresh fruits & \\
\hline Foeniculum vulgare L. & 0.13 & Apiaceae & wild fennel & finocchio selvatico & $\begin{array}{l}\text { stems (I), leaves (II), } \\
\text { seeds (III) }\end{array}$ & $\begin{array}{l}\text { liqueurs (I), flavouring (II, III), } \\
\text { mixed vegetables (I) }\end{array}$ & \\
\hline Gentiana lutea L.* & 0.03 & Gentianaceae & great yellow gentian & genziana & roots & liqueurs & \\
\hline Humulus lupulus L.* & 0.03 & Cannaboideae & common hop & luppolo & shoots & pasta sauce & \\
\hline Juglans regia L. & 0.10 & Juglandaceae & walnut & noce & fruits & liqueurs, fresh fruits & \\
\hline Juniperus communis L. & 0.15 & Juniperoideae & common juniper & ginepro & fruits & flavouring, liqueurs & \\
\hline Laurus nobilis L. & 0.10 & Lauraceae & bay laurel & alloro & leaves & flavouring, liqueurs & \\
\hline
\end{tabular}


Table 1 List of the wild food plants used in the study area (Continued)

\begin{tabular}{|c|c|c|c|c|c|c|c|}
\hline Lippia citriodora Kuntze & 0.08 & Verbenaceae & lemon verbena & erba luigia & leaves & liqueurs & Swelling trauma (decoction) \\
\hline Lonicera caprifolium L. & 0.08 & Caprifoliaceae & sweet honeysuckle & caprifoglio/ligabôsc & shoots & salads & \\
\hline Malus sylvestris (L.) Mill** & 0.03 & Rosaceae & European crab apple & melo selvatico & fruits & fresh fruits & \\
\hline Medicago sativa L.** & 0.03 & Fabaceae & alfalfa & erba medica/spagna & leaves & salads, mixed vegetables & \\
\hline Melissa officinalis L.* & 0.03 & Lamiaceae & lemon balm & melissa, erba limone & leaves & flavouring & \\
\hline Mentha spp. & 0.13 & Lamiaceae & $\operatorname{mint}$ & menta & leaves & flavouring, liqueurs & Digestive (decoction) \\
\hline Mespilus germanica L. & 0.05 & Rosaceae & medlar & nespolo & fruits & fresh fruits & \\
\hline Morus spp. & 0.05 & Moraceae & mulberry & mora & fruits & fresh fruits & \\
\hline Papaver rhoeas L. & 0.05 & Papaveraceae & field poppy & papavero/rosetta & young leaves & $\begin{array}{l}\text { salads, pan-fried, mixed } \\
\text { vegetables }\end{array}$ & \\
\hline Portulaca oleracea L. & 0.05 & Portulacaceae & purslane & portulaca & leaves & salads, liqueurs & \\
\hline Primula spp. & 0.10 & Primulaceae & primrose & primula & flowers (I), leaves (II) & $\begin{array}{l}\text { salads (I), rural snacks (I), } \\
\text { pasta stuffing (II) }\end{array}$ & \\
\hline Prunus avium L. & 0.05 & Rosaceae & wild cherry & ciliegio selvatico & fruits & fresh fruits & \\
\hline Prunus cerasifera Ehrh. & 0.10 & Rosaceae & myrobalan plum & mirabolano/rustican & fruits & rural snacks & \\
\hline Prunus cerasus L. & 0.05 & Rosaceae & sour cherry & amareno/visciole & fruits (I), leaves (II) & fresh fruits (I), liqueurs (II) & \\
\hline Prunus laurocerasus L. & 0.05 & Rosaceae & lauroceraso & lauroceraso/lauro & fruits & liqueurs & \\
\hline Prunus spinosa L. & 0.28 & Rosaceae & sloe & $\begin{array}{l}\text { prugnolo selvatico/prugnól, } \\
\text { spini, strozchi }\end{array}$ & fruits & rural snacks, liqueurs & \\
\hline Punica granatum L.* & 0.03 & Punicaceae & pomegranate & melograno & fruits & fresh fruits & \\
\hline Pyrus pyraster Burgsd & 0.05 & Rosaceae & wild pear & pero selvatico & fruits & fresh fruits & \\
\hline Robinia pseudoacacia L. & 0.21 & Fabaceae & black locust & acacia/acâg & flowers & pancakes, rural snacks & \\
\hline Rosa spp. & 0.28 & Rosaceae & dog rose & rosa selvatica/pizzincul (fruits) & $\begin{array}{l}\text { shoots (II), fruits (II), } \\
\text { flowers (III) }\end{array}$ & rural snack (I, II), jams (II, III) & \\
\hline Rosmarinus officinalis $\mathrm{L}$. & 0.13 & Lamiaceae & rosemary & rosmarino & leaves & flavouring, liqueurs & $\begin{array}{l}\text { Digestive (decoction); } \\
\text { decongestant (fumigations) }\end{array}$ \\
\hline Rubus spp. & 0.31 & Rosaceae & wild blackberry & rovo/râza & fruits (I), shoots (II) & $\begin{array}{l}\text { fresh fruits }(I) \text {, liqueurs }(I) \text {, } \\
\text { jams }(I) \text {, rural snacks }(I I)\end{array}$ & \\
\hline Rumex acetosa $\mathrm{L}$. & 0.15 & Polygonaceae & sorrel & acetosa/êrba brossca & leaves & rural snacks & \\
\hline Ruscus aculeatus L.* & 0.03 & Ruscaceae & butcher's broom & pungitopo & shoots & pan-fried & \\
\hline Salvia pratensis $\mathrm{L}$. & 0.10 & Lamiaceae & meadow clary & salvia selvatica & leaves & $\begin{array}{l}\text { salads, flavouring, omelettes, } \\
\text { liqueurs }\end{array}$ & $\begin{array}{l}\text { Digestive (decoction); female } \\
\text { genital problems (infusion); } \\
\text { toothpaste (fresh leaves) }\end{array}$ \\
\hline Sambucus nigra L. & 0.21 & Adoxaceae & elderberry & sambuco & fruits (I), flowers (II) & $\begin{array}{l}\text { jams (I, II), pancakes (II), } \\
\text { liqueurs (II) }\end{array}$ & Antirheumatic (food: jam) \\
\hline Sanguisorba minor Scop. & 0.05 & Rosaceae & salad burnet & pimpinella/pampinela & leaves & salads & \\
\hline
\end{tabular}


Table 1 List of the wild food plants used in the study area (Continued)

\begin{tabular}{|c|c|c|c|c|c|c|c|}
\hline Satureja hortensis L.* & 0.03 & Lamiaceae & summer savory & santoreggia & leaves & flavouring & \\
\hline $\begin{array}{l}\text { Silene vulgaris (Moench) } \\
\text { Garcke }\end{array}$ & 0.26 & Caryophyllaceae & bladder campion & $\begin{array}{l}\text { silene rigonfia/stridel, } \\
\text { ciucchett }\end{array}$ & young leaves & $\begin{array}{l}\text { salads, pan-fried, pasta sauce, } \\
\text { pasta dough, omelettes }\end{array}$ & \\
\hline $\begin{array}{l}\text { Sonchus asper L. (Hill)/ } \\
\text { Sonchus arvensis L. }\end{array}$ & 0.33 & Asteraceae & sow thistles & grespino/frabbs & young leaves & pan-fried, salads & $\begin{array}{l}\text { Depurative, diuretic, laxative } \\
\text { (food) }\end{array}$ \\
\hline Sorbus domestica L. & 0.13 & Rosaceae & seviceberry & sorbo & fruits & fresh fruits & \\
\hline Tanacetum balsamita L.* & 0.03 & Asteraceae & costmary & erba di santa Maria & leaves & liqueurs & \\
\hline Taraxacum officinale Weber & 0.77 & Asteraceae & swines snout & tarassaco/piscialet & young leaves & $\begin{array}{l}\text { salads, pan-fried, omelettes, } \\
\text { mixed vegetables }\end{array}$ & $\begin{array}{l}\text { Depurative, refreshing, } \\
\text { draining, diuretic (food, } \\
\text { cooking water) }\end{array}$ \\
\hline Thymus spp. & 0.08 & Lamiaceae & thyme & timo & leaves & flavouring & \\
\hline Trifolium pratense L.* & 0.03 & Fabaceae & red clover & trifoglio dei prati & flowers & rural snacks & \\
\hline Urtica spp. (dioica, urens) & 0.74 & Urticaceae & nettle & ortica & leaves & $\begin{array}{l}\text { pasta stuffing and dough, salads, } \\
\text { omelettes, mixed vegetables }\end{array}$ & $\begin{array}{l}\text { Refreshing, kidney problems, } \\
\text { mineralizing (food, cooking } \\
\text { water); hair strength, shine, } \\
\text { dandruff (cooking water); } \\
\text { anti- arthritic (fresh leaves } \\
\text { rubbed on the body); insecti- } \\
\text { cide (leaves macerated in } \\
\text { water) }\end{array}$ \\
\hline $\begin{array}{l}\text { Valerianella locusta L. } \\
\text { (Laterrade) }\end{array}$ & 0.41 & Valerianaceae & lamb's lettuce & valerianella/grassagallina & leaves & salads & \\
\hline Viola spp. & 0.08 & Violaceae & violet & viola & flowers & salads & \\
\hline $\begin{array}{l}\text { Vitis vinifera L. subsp. } \\
\text { Sylvestris (Gmelin) Hegi }\end{array}$ & 0.13 & Vitaceae & wild grape & vite selvatica & $\begin{array}{l}\text { fruits (I), shoots (II), } \\
\text { leaves (III) }\end{array}$ & $\begin{array}{l}\text { fresh fruits (I), rural snacks (II), } \\
\text { mixed vegetables (III) }\end{array}$ & \\
\hline
\end{tabular}

\section{Folk Italian names are written in italics.}

Roman numbers indicate the correlation between the traditional culinary use and a specific part of the plant.

*indicates plant species mentioned by a single informant.

RFC: Relative Frequency of Citation Index.

Medicinal use: in brackets the way plants or parts of it are prepared and administered to give the mentioned therapeutic effect. 
the present study were compared with an ethnobotanical survey conducted around Lake Vrana (northern Dalmatia, Croatia) [28] based on a similar number of informants (43) and mentioned wild food plants (57). Wild vegetables are still widely used in the Lake Vrana area. In fact, although less popular among young people, old and middle aged people still retain wide knowledge and collect them. The average number of species quoted is higher in Lake Vrana area (12.4) than in Bologna's territory (9.8) on the contrary to the percentage of plant species mentioned by a single informant (14\% for Lake Vrana study and $29 \%$ in the present study). This comparison confirms the highly eroded nature of wild food plants knowledge in the area of Bologna.

The folk plant species mentioned by the people interviewed in the present study belonged to 33 different botanical families (Table 2). The most representative families were the Rosaceae (14 plants) and the Asteraceae (9 plants). The parts of the plants used and recorded for each mentioned species are represented in Figure 2. In general, leaves were most frequently used (33), followed by fruits (24) and shoots (9). The ways of consumption of wild food plants and the number of species in each category are shown in Figure 3. Plants were most often consumed raw, in salads prepared with the tender young leaves (25) collected in the early vegetative rosetta stage when they have a less bitter taste, or boiled. They are also frequently used as liqueur ingredients (17), a habit still in use, or eaten as fresh fruits (14). In the past, some wild plant parts were extemporaneously eaten raw as a rural snack (13, Figure 3 ) by kids and collecting them was often experienced as a competing game. Rural snacks consisted mainly of berries, but also of young shoots, leaves and flowers, such as those of Primula spp. L., Trifolium pratense L and Robinia pseudoacacia L., from which, in particular in case of the latter, the sweet nectar was sucked. In addition to flowers and ripe fruits, kids were often attracted by the sour taste of unripe wild fruits and young shoots. The only rural snack consumed as leaves was Rumex acetosa L. popularly known as "erba brossca" which means in fact sour grass.

In general, the Asteraceae wild greens were cooked by pan-frying or consumed together with other wild plants as mixed vegetables (Figure 3 and Table 1).

The plant species of the present study (area of Bologna, northern Italy) were compared with those listed by two Italian ethnobotanical surveys focused in wild food plants traditions and carried out in Castelmezzano village and in the Graecanic area (Lucania and Calabria region, southern Italy) $[25,26]$. From a general point of view, among the three study areas most of the recorded plant species are common, like most of the wild fruits and some Asteraceae plants. On the other hand, some specific differences could be pointed out such as for thistles (Carlina acaulis L., Cynara cardunculus L. ssp. cardunculus, Silybum
Table 2 Botanical families of wild food plants traditionally consumed in the study area

\begin{tabular}{|c|c|}
\hline Botanical family & $\mathrm{N}^{\circ}$ of wild food plant species \\
\hline Rosaceae & 14 \\
\hline Asteraceae & 9 \\
\hline Lamiaceae & 7 \\
\hline Fabaceae & 3 \\
\hline Brassicaceae & 2 \\
\hline Fagaceae & 2 \\
\hline Liliaceae & 2 \\
\hline Moraceae & 2 \\
\hline Adoxaceae & 1 \\
\hline Apiaceae & 1 \\
\hline Asparagaceae & 1 \\
\hline Boraginaceae & 1 \\
\hline Cannaboideae & 1 \\
\hline Caprifoliaceae & 1 \\
\hline Caryophyllaceae & 1 \\
\hline Cornaceae & 1 \\
\hline Corylaceae & 1 \\
\hline Juniperoideae & 1 \\
\hline Gentianaceae & 1 \\
\hline Juglandaceae & 1 \\
\hline Lauraceae & 1 \\
\hline Papaveraceae & 1 \\
\hline Polygonaceae & 1 \\
\hline Portulacaceae & 1 \\
\hline Primulaceae & 1 \\
\hline Punicaceae & 1 \\
\hline Ranuncolaceae & 1 \\
\hline Ruscaceae & 1 \\
\hline Urticaceae & 1 \\
\hline Valerianaceae & 1 \\
\hline Verbenaceae & 1 \\
\hline Violaceae & 1 \\
\hline Vitaceae & 1 \\
\hline
\end{tabular}

marianum L., Scolymus hispanicus L.) which are collected and consumed by both people of Castelmezzano and Graecanic area but in Bologna. Conversely, species like Sanguisorba minor Scop., widely known as "pampinela", and Urtica spp., are still very popular and used in Bologna's territory, but were not present in the other two surveys $[25,26]$.

\section{Folk plant classification and folk names}

Folk plant names were mentioned by the informants according to their own plant classification (folk systematic) in 


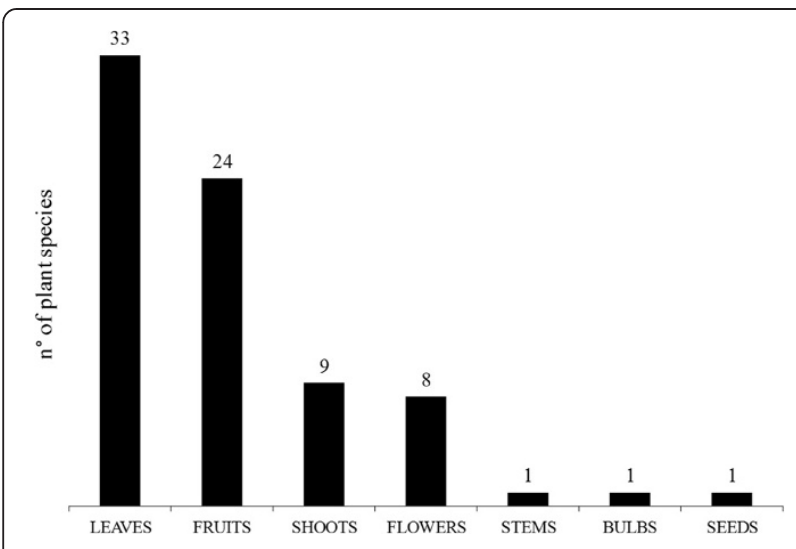

Figure 2 Parts of the wild food plants traditionally consumed in the study area. The number above each bar indicates the total number of species used in each category.

which the elementary unit is represented by a folk generic, also called ethnospecies (as defined by [29]), recognizable on the basis of differences in macro-morphology, habitat and use of the plant [30]. The present survey evidenced that, in several cases, more than one related plant species that cannot be distinguished by a non-expert were assimilated and identified as a single ethnospecies (under differentiation). It should be noted that wild food plants were usually collected at the rosette stage or as young shoots, when the plant lacks a flower, the most important botanical identification character. This is the case for folk plants commonly named "frabbs", a term that equally refers to two species, Sonchus asper L. and Sonchus arvensis L., that are morphologically related but have a different leaf shape. As these two species have a similar taste, they were indiscriminately used and, therefore, share the same folk name. Analogously, the word "radećc" was equally assigned to Cichorium intybus L., Sonchus spp. L. and Crepis spp., a large group of plants of which the basal leaves were collected in the same period of the year (end of winter -

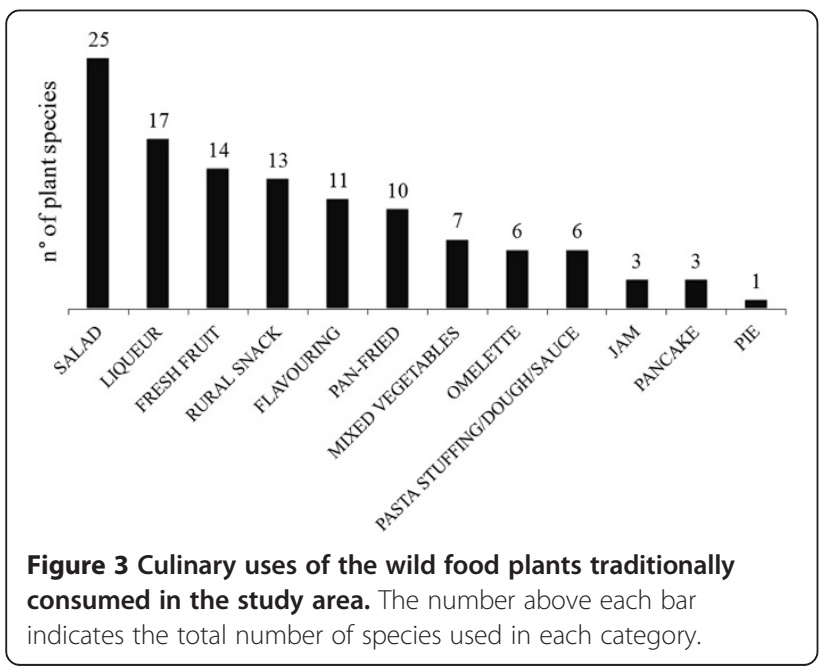

beginning of spring, sometimes early autumn), eaten raw (tender leaves of young plants) or boiled (bigger older leaves collected in the late vegetative stage), and cooked in a similar way. In Dalmatia (southern Croatia), an analogous group of species (mainly C. intybus L. and Crepis spp.), belonging to Cichorioideae (Asteraceae family), are similarly called "radić" and collected as rosette basal leaves [31]. In general, plant names of folk systematic are not useful for botanical identification but rather associated to practical purposes and final use. In addition, plant folk names may be related to botanical characteristics, habitat, taste or the relationship between man and those plants. Our study pointed out several folk names which relate to a botanical character, such as "strecapugno", which means "clenched in a fist", referring to C. vesicaria subsp. taraxacifolia (Thuill) Thell (Table 1). In fact, local people know that this plant, after being cut from the ground, is going to rapidly close on itself and so they must clean it immediately after collection. Piscialét refers to the diuretic property of $T$. officinale Weber. As earlier mentioned, C. intybus L. was commonly indicated as "radećć" but also more specifically as "radećć cavdagn", suggesting that this species belonging to the radećć category was mostly found along small country roads (cavdagn). Other examples of meaningful folk names are the above-mentioned "erba brossca", which refers to the acid taste of Rumex acetosa L. leaves, and "ciucchett", a onomatopoeic word that matches the popping sound produced when Silene vulgaris (Moench) Garcke flowers, which have a balloon-like capsule, are squeezed.

\section{Medicinal use of wild food plants}

Eleven plant species were also mentioned as having therapeutic effects (Table 1). A few of these, after specific therapeutic preparation, were used as medicine without any direct relation to their alimentary use. Lippia citriodora Kuntze, Salvia pratensis L., Mentha spp., Rosmarinus officinalis L., all belonging to the Lamiaceae family, were used to make a decoction for digestive purposes. In addition, $L$. citriodora Kuntze leaf decoction was applied to treat muscular and articular pains after a trauma, S. pratensis L. was used for female genital problems (infusion) and as toothpaste (fresh leaves), while $R$. officinalis L. was utilized as a decongestant (fumigations). The flower infusion of $\mathrm{Cra}$ taegus monogyna Jacq. was reported to be relaxing, to facilitate sleep and to be useful for heart problems. Other folk plants were reported to have therapeutic effects when part of the everyday diet. The wild species with the highest number of cited medicinal uses was Urtica spp., which if consumed with the diet or as cooking water, was reported to be refreshing, mineralizing and active against kidney problems. Moreover, Urtica cooking water was often used as shampoo to improve hair strength and shine and to eliminate dandruff. Other applications were as a remedy for arthritis (by rubbing fresh leaves on the aching areas of 
the body) and as insecticide (using macerated leaves). Some plants, in particular T. officinale Weber, C. vesicaria subsp. taraxacifolia (Thuill) Thell and Sonchus spp. were defined as functional foods [32] having depurative, blood cleaning and refreshing effects. Besides, T. officinale Weber, C. vesicaria subsp. taraxacifolia (Thuill) Thell (of which informants reported to also drink the cooking water) and Crepis sancta (L.) Babc. were in general reported to have diuretic and laxative actions so that these plants may all be considered medicinal foods [32]. Finally, Sambucus nigra L. consumed as jam was mentioned to relieve bone problems like rheumatisms.

\section{Perception and health impact of wild food plants}

During the interviews, the informant's perceptions regarding the impact of wild food plants on human nutrition and health, as well as the differences between wild, selfcultivated and large-scale cultivated edible plants were also investigated. All people interviewed perceived wild plants as being the healthiest for humans because they grow naturally without man's intervention and, consequently, they are likely to contain the highest amounts of nutrients and beneficial substances. The respondents also perceived self-cultivated plants as better than those produced on a large-scale and purchased in stores because the exact process in this case was unknown.

\section{Taste of the collected wild food plants}

Among the secondary metabolites produced by plants, phenolics, terpenes and alkaloids [33] are those that mainly contribute to the bitter, sour or astringent tastes [34-36]. These substances mostly accumulate in leaves and shoots, but also in flowers and roots and, among other effects, provide a defence against herbivorous predators by making the plant unpalatable [34]. Although potentially beneficial to human health in small doses, many of such compounds are, in fact, toxic [37]. Among the previously listed wild plants (Table 1), those reported to be the most bitter were Clematis vitalba L., T. officinale Weber and C. vesicaria subsp. taraxacifolia (Thuill) Thell, with the different degree of bitterness depending on individual perception. A wild edible plant with a particular strong flavour similar to arugula is Diplotaxis tenuifolia L. (DC) that, for this reason, was always used in combination with other vegetables. Instead, a delicate sweet flavour, also appreciated by children (often reluctant to eat wild greens because of their bitterness), was reported for Silene vulgaris (Moench) Garcke and for Valerianella locusta L. (Laterrade) which, therefore, were also eaten raw in salads (Table 1, Figure 3).

\section{Conclusions}

The present study was aimed at documenting the traditional knowledge on wild food plants in a study area belonging to the province of Bologna (Emilia-Romagna region, Italy) (Figure 1) that had not been previously investigated by any other ethnobotanical research performed in Italy. The obtained results may allow to preserve part of the local cultural heritage that seems to be quickly disappearing along with the people, some of them very elderly, who still retain this type of knowledge. The popular traditions regarding wild food plants of the territory of Bologna are, in fact, being progressively lost because they are not handed down to new generations anymore, so that today young people do not acquire any information regarding wild edibles that characterized the diet of their forebears. Presumably, the high rate of immigration and the high level of urbanization also greatly contributed to the erosion of TLK. In particular the immigration phenomenon (from other areas of Italy and from abroad) has led to a mixture of traditions related to the use of wild food plants that partially overlap and influence each other. The present survey revealed that, in spite of the loss of TLK, the use of wild food plants in the area of Bologna is being revaluated today because these plants are perceived as healthy and represent the preservation of biodiversity as well as a way of getting back to nature.

In the era of large-scale distribution, which has generally led to a decrease in food quality, the interest in wild edibles is increasingly gaining media attention. In Italy and in many other European countries, it is possible to find guide books, workshops, and new culinary vogues associated with wild edible plants. A great impulse to this increased interest has also been given by the gastronomy elite, always in search for new stimuli, culinary experiences and healthy food, but also by agritourism farms and local rural restaurants desirous to put dishes of the traditional culinary heritage on their menus. Our contribution in preserving local knowledge and traditions will hopefully reinforce this new growing trend to become a habit, so as to enrich the local diet with new "old traditional" foods beneficial for human health.

\section{Additional file}

Additional file 1: Questionnaire form Guidelines followed during

the semi-structured interviews of the ethnobotanical survey.

\section{Competing interests}

The authors declare that they have no competing interests.

\section{Authors' contributions}

SS conducted the fieldwork, analysed the data, and drafted the manuscript. AT supervised the research, and critically reviewed the manuscript. All authors have read and approved the final manuscript.

\section{Acknowledgements}

We wish to thank Dr. Annalisa Managlia (Herbarium of the University of Bologna) and Dr. Umberto Mossetti (Curator of the Botanical Garden of the University of Bologna) for their valuable help in the botanical identification 
of the collected samples; Mr. Luca Magagnoli (Botanical Garden of the University of Bologna) for his precious support in the collection of wild food plant samples and Mr. Nicodemo Mele (University of Bologna) for helping in editing colour pictures. This work was supported by RFO 2010 and 2011 funding (University of Bologna) to Annalisa Tassoni. We are very thankful to Dr. Marianne Louise van Buuren for the editing of the English language.

Received: 11 March 2014 Accepted: 27 August 2014

Published: 25 September 2014

\section{References}

1. Cederna C: Nostra Italia del miracolo. Milano: Longanesi; 1980

2. Targioni-Tozzetti G: Alimurgia o sia modo di render meno gravi le carestie proposto per sollievo de' poveri (etc.). Firenze: Moucke; 1767.

3. Sakarkar DM, Deshmukh VN: Ethnopharmacological review of traditional medicinal plants for anticancer activity. Int J PharmTech Res 2011, 3:298-308.

4. Silva JRA, Ramos A d S, Machado M, Moura DF, Neto Z, Canto-Cavalheiro MM, Figueiredo P, Rosário VE, Amaral ACF, Lopes D: A review of antimalarial plants used in traditional medicine in communities in Portuguese-Speaking countries: Brazil, Mozambique, Cape Verde, Guinea-Bissau, São Tomé and Príncipe and Angola. Mem Inst Oswaldo Cruz 2011, 106:142-158.

5. Paoletti MG, Dreon AL, Lorenzoni GG: Pistic, traditional food from Western Friuli, N.E. Italy. Econ Bot 1995, 49:26-30.

6. Pardo-de-Santayana M, Tardío J, Morales $R$ : The gathering and consumption of wild edible plants in the Campoo (Cantabria, Spain). Int J Food Sci Nutr 2005, 56:542.

7. Łuczaj Ł, Köhler P, Piroznikow E, Graniszewska M, Pieroni A, Gervasi T: Wild edible plants of Belarus: from Rostafiński's questionnaire of 1883 to the present. J Ethnobiol Ethnomed 2013, 9:1-21.

8. Sanchez-Mata MC, Cabrera Loera RD, Morales P, Fernandez-Ruiz V, Cámara $M$, Díez Marqués C, Pardo-de-Santayana M, Tardío J: Wild vegetables of the Mediterranean area as valuable sources of bioactive compounds. Gen Resour Crop Ev 2012, 59:431-443.

9. Pereira C, Barros L, Carvalho AM, Ferreira ICFR: Nutritional composition and bioactive properties of commonly consumed wild greens: Potential sources for new trends in modern diets. Food Res Int 2011, 44:2634-2640.

10. The Local Food-Nutraceuticals Consortium: Understanding local Mediterranean diets: a multidisciplinary pharmacological and ethnobotanical approach. Pharmacol Res 2005, 52:353-366.

11. Trichopoulou A, Vasilopouloua E, Hollmanb P, Chamalidesc C, Foufac E, Kaloudisd T, Kromhoute D, Miskakid P, Petrochiloud I, Poulimac E, Stafilakisc K, Theophilouc D: Nutritional composition and flavonoid content of edible wild greens and green pies: a potential rich sources of antioxidant nutrients in the Mediterranean diet. Food Chem 2000 70:319-323.

12. Leonti $M$, Nebel $S$, Rivera $D$, Heinrich $M$ : Wild gathered food plants in the European Mediterranean: a comparative analysis. Econ Bot 2006, 60:130-142.

13. Pieroni A, Janiak V, Dürr CM, Lüdeke $S$, Trachsel $E$, Heinrich M: In vitro antioxidant activity of non-cultivated vegetables of ethnic Albanians in Southern Italy. Phytother Res 2002, 16:467-473.

14. Finkel T, Holbrook NJ: Oxidants, oxidative stress and the biology of ageing. Nature 2000, 408:239-247.

15. Maritim AC, Sanders RA, Watkins JB III: Diabetes, oxidative stress, and antioxidants: A Review. J Biochem Mol Toxic 2003, 17:24-38.

16. Pieroni A, Giusti ME, de Pasquale C, Lenzarini C, Censorii E, Reyes GonzálesTejero M, Sánchez-Rojas CP, Ramiro-Gutiérrez JM, Skoula M, Johnson C, Sarpaki A, Della A, Paraskeva-Hadijchambi D, Hadjichambis A, Hmamouchi M, El-Jorhi S, El-Demerdash M, El-Zayat M, Al-Shahaby O, Houmani Z, Scherazed M: Circum-Mediterranean cultural heritage and medicinal plant uses in traditional animal healthcare: a field survey in eight selected areas within the RUBIA project. J Ethnobiol Ethnomed 2006 2:16-28.

17. Hadjichambis AC, Paraskeva-Hadjichambi DP, Della A, Giusti ME, De Pasquale C, Lenzarini C, Censorii E, Gonzales-Tejero MR, Sanchez-Rojas CP, Ramiro-Gutierres JM, Skoula M, Johnson C, Sarpaki A, Hmamouchi M, Jorhi S, El-Demerdash M, El-Zayat M, Pieroni A: Wild and semi-domesticated food plant consumption in seven circum-Mediterranean areas. Int J Food Sci Nutr 2008, 59:383-414.
18. Ghirardini MP, Carli M, Del Vecchio N, Rovati A, Cova O, Valigi F, Agnetti G, Macconi M, Adamo D, Traina M, Laudini F, Marcheselli I, Caruso N, Gedda T, Donati F, Marzadro A, Russi P, Spaggiari C, Bianco M, Binda R, Barattieri E, Tognacci A, Girardo M, Vaschetti L, Caprino P, Sesti E, Andreotti G, Coletto E, Belzer G, Pieroni A: The importance of a taste. A comparative study on wild food plant consumption in twenty-one local communities in Italy. J Ethnobiol Ethnomed 2007, 3:1-22.

19. Łuczaj Ł, Pieroni A, Tardío J, Pardo-de-Santayana M, Sõukand R, Svanberg I, Kalle R: Wild food plant use in 21st century Europe: the disappearance of old traditions and the search for new cuisines involving wild edibles. Acta Soc Bot Pol 2012, 81:359-370.

20. Alexiades MN: Collecting ethnobotanical data: an introduction to basic concepts and techniques. In Selected Guidelines for Ethnobotanical Research: A Field Manual. Edited by Alexiades MN. New York: The New York Botanical Garden; 1996:53-94.

21. Tardio J, Pardo-De-Santayana M: Cultural importance indiced: a comparative analysis based on the useful wild plants of Southern Cantabria (Northern Spain). Econ Bot 2008, 62:24-39.

22. Pignatti S: Flora d'Italia. Bologna: Edagricole; 1982.

23. Ungaretti G: Le piante aromatiche e medicinali nei nomi nell'uso e nella tradizione popolare bolognese. Bologna: Arnaldo Forni Editore; 1921.

24. Forbes MHC: Gathering in the Argolid: a subsistence subsystem in a Greek agricultural community. Ann NY Acad Sci 1976, 268:251-264.

25. Nebel S, Pieroni A, Heinrich M: Wild edible greens used in the Graecanic area in Calabria, Southern Italy. Appetite 2006, 47:333-342.

26. Pieroni A, Nebel S, Heinrich M: Food for two reasons: culinary uses of non-cultivated local vegetables and mushrooms in a south Italian village. Int J Food Sci Nutr 2005, 56:245-272.

27. Picchi G, Pieroni A: Atlante dei prodotti tipici. Le erbe. Roma: Rai - AGRA; 2005

28. Łuczaj Ł, Fressel N, Perković S: Wild food plants used in the villages of the Lake Vrana Nature Park (northern Dalmatia, Croatia). Acta Soc Bot Pol 2013, 82:275-281.

29. Signorini MA, Lombardini C, Bruschi P, Vivona L: Conoscenze etnobotaniche tradizionali nel territorio di San Miniato (Pisa). Atti Soc tosc Sci nat, Mem Serie B 2007, 114:65-83.

30. Berlin B, Breedlove DE, Raven PH: General principles of classification and nomenclature in folk biology. Am Anthropol 1973, 75:214-242.

31. Łuczaj $Ł$, Končić MZ, Miličević T, Dolina K, Pandža M: Wild vegetable mixes sold in the markets of Dalmatia (southern Croatia). J Ethobiol Ethnomed 2013, 9:2.

32. Pieroni $A$, Quave $C L$ : Functional food or food medicines? On the consumption of wild plants among Albanians and southern Italians in Lucania. In Eating and Healing: traditional food as medicine. Edited by Pieroni A, Price LL. New York: Haworth Press; 2006:101-129.

33. Bourgaud F, Gravot A, Milesi S, Gontier E: Production of plant secondary metabolites: a historical perspective. Plant Sci 2001, 161:839-851.

34. Bravo L: Polyphenols: chemistry, dietary sources, metabolism, and nutritional significance. Nutr Rev 1998, 56:317-333.

35. Rouseff RL: Bitterness in food products: an overview. In Bitterness in foods and beverages; developments in food science, Volume 25. Edited by Rouseff RL. Amsterdam: Elsevier Science Publishers BV; 1990:1-14.

36. Drewnowski $A$, Rock $C L$ : The influence of genetic taste markers on food acceptance. Am J Clin Nutr 1995, 62:506-511.

37. Ames BN, Profet M, Gold LS: Dietary pesticides ( $99.99 \%$ all natural). Proc Natl Acad Sci U S A 1990, 87:7777-7781

\section{doi:10.1186/1746-4269-10-69}

Cite this article as: Sansanelli and Tassoni: Wild food plants traditionally consumed in the area of Bologna (Emilia Romagna region, Italy). Journal of Ethnobiology and Ethnomedicine 2014 10:69. 